\title{
ASSESSMENT OF THE CHANGE IN RIVER DISCHARGE-CARRYING CAPACITY USING REMOTE SENSING GEOGRAPHIC INFORMATION SYSTEM: A CASE STUDY OF OFU RIVER, NIGERIA
}

\author{
M. I. Alfa ${ }^{1 *}$, M. A. Ajibike ${ }^{2}$ and D. B. Adie ${ }^{3}$ \\ 1,Department of Civil EngineERIng, University of Jos, Jos, Plateau State, NIGERIA

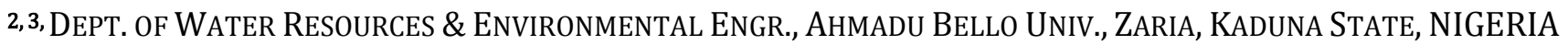 \\ E-mail addresses:1meshilalfa@gmail.com, 2ajibikefarida2012@gmail.com,3donadie2005@yahoo.com
}

\begin{abstract}
This study assessed the changes in the flow carrying capacity of Ofu River in Nigeria between 2000 and 2011 using the DEMs of the respective years. The results showed that Ofu River had lost $12.88 \mathrm{~m}$ amounting to about $42.58 \%$ of its flow depth at Oforachi between 2000 and 2011 at a rate of $1.171 \mathrm{~m}$ per year and an estimated $18.74 \mathrm{~m}$ amounting to about $61.95 \%$ in 2016 . The Total sediment load was $66,825,730 \mathrm{~kg} /$ year comprising of $56,747,260 \mathrm{~kg} /$ year and $10,077,470 \mathrm{~kg} /$ year of measured and unmeasured sediment loads respectively. The results obtained suggested that the loss in flow depth is a result of siltation of the river bed due to the high sediment load probably as a result of soil cultivation within the floodplains. The study demonstrated that remote sensing and GIS can be used to assess the changes in the discharge-carrying capacity of a river.
\end{abstract}

Keywords: DEM, Discharge capacity, Flow depth, GIS, Ofu river, Sediment load

\section{INTRODUCTION}

Flood has been widely considered by researchers to be one of the most devastating and frequently occurring natural hazards in the world $[1,2,3,4]$. It is regarded as the costliest natural disaster in the world responsible for more than $30 \%$ of all geophysical related hazards, adversely affecting more people than any other natural hazard globally $[3,5,6]$ and accounting for about $31 \%$ of economic losses globally [7]. Flood has been generally defined as the flow of water above the carrying capacity of a channel $[8,9]$. Among the various types of flood, the river or fluvial flood is directly connected to the ability of the stream channel to carry flood water. River or Fluvial flood occurs on floodplains of rivers as a result of flow exceeding the discharge carrying-capacity of the stream channels thereby over spilling the banks [10]. This implies that an assessment of the discharge carrying capacity of a river is very important in the study of the flood potentials of the same river.

There is a yearly occurrence of floods of different severity within the Ofu River sub-basin covering parts of Dekina, Ofu, Igalamela/Odolu, Idah and Ibaji Local Government Areas in Kogi State and parts of UzoUwani LGA in Enugu State, Nigeria which are attributable to the inability of Ofu River to carry the amount of runoffs that it receives during the peak of the rainy season. These have resulted in loss of valuable properties, destruction of infrastructure, livestock and crops. It therefore becomes important to assess the extent to which this loss has affected the discharge carrying capacity of the river using Geographic Information System (GIS) and remote sensing as a knowledge base for its flood risk assessment.

\section{MATERIALS AND METHODS}

\subsection{The Study Area}

Ofu River catchment lies between latitudes $6^{\circ} 46^{\prime} \mathrm{N}$ and $7^{\circ} 39^{\prime} \mathrm{N}$ and longitudes $6^{\circ} 42^{\prime} \mathrm{E}$ and $7^{\circ} 21^{\prime} \mathrm{E}$ (Fig. 1) covering parts of Dekina, Ofu, Igalamela/Odolu, Idah and Ibaji Local Government Areas in Kogi State and Uzo-Uwani Local Government Area in Enugu State, Nigeria, within the humid tropical rain forest of Nigeria [11]. The study area falls within the Lower Benue River Basin Development Authority in North Central Nigeria. Figure 1 shows the Map of Nigeria showing the study area. Rainfall within the catchment is concentrated in one season lasting from April/May to September/October. 


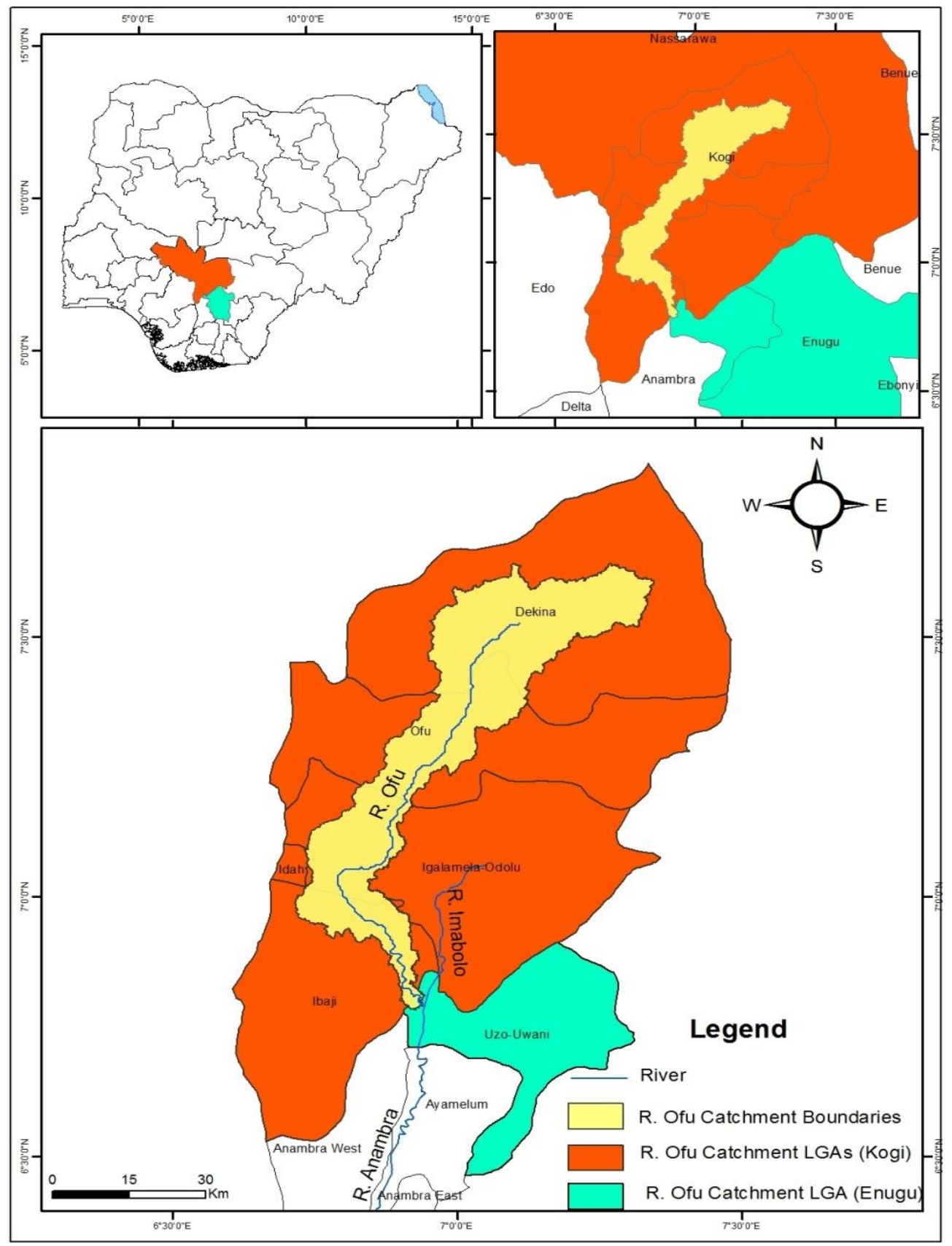

Figure 1: Map of Study Area [11]

The main River within the catchment (Ofu River) is perennial and parallel in pattern to Imabolo and Okura rivers which are close to the study area. It took its root from Ojofu, in Dekina Local Government area in Kogi State flowing in the eastward direction with a catchment area amounting to about $1,604 \mathrm{~km}^{2}$ [12] most of which is covered by dense forest. Okura River joined Imabolo River in Egabada (Kogi State) and further flow southwards before joining the Ofu River and the 'three-in-one' river empties into the famous Anambra River in Anambra State [13]. The river is controlled by direct rainfall into the stream channel, surface runoff from the fields around and close to the main rivers and from ground water discharge. The peak flow is obtained during the wet season in the month of September which causes flooding of nearby fields. The catchment is characterized of dry season of about 5 months (November to March) during which the flow in the River Ofu is maintained by ground water outflow. The peak of rainy season (June to October) accounts for $96 \%$ of the total annual flow [14].

\subsection{Evaluation of Change in Discharge Carrying Capacity} The assessment of the change in the carrying capacity of the Ofu River Channel was carried out using the Shuttle Radar Topographic Mission (SRTM) 1 arc- 
second Global (SRTMGL1) Digital Elevation Model (DEM) version 3 of 2000 and Advanced Space borne Thermal Reflection Radiometer Global Digital Elevation Model (ASTER-GDEM) version 2 of 2011 both obtained from the United States Geological Surveys (USGS) Earth Explorer online portal (https://earthexplorer.usgs.gov). Both DEMs were provided in $1^{\circ} \times 1^{\circ}$ tiles at 1 arc-second $(30 \mathrm{~m})$ resolution and were on WGS84 datum. Also, both are referenced to mean sea level realized by the EGM 96 geoid model. Both DEMs are Digital Terrain Model which gives the ground elevation.

The change in volume, surface area and Channel bed elevation for 29 sections of the river were calculated using the 3D Analyst Tools in ArcGIS 10.2.2. Although the sections were randomly selected across the entire span of the River, care was taken to ensure that they were spread around Oforachi where the actual field work was carried out. The DEMs of 2000 and 2011 were respectively converted to triangulated Irregular Network (TIN) surfaces (Fig. 2) using the 3D Analyst Conversion Tool after which Polygon shape files for the 29 sections along the river channel were created in ArcCatalogue as shown in Fig. 3. They were respectively projected to the same coordinate as the DEMs (WGS_1984_UTM_Zone_32N). These were used as the reference polygons.

The reference height for each of the reference polygons were specified in the respective attribute tables of the reference polygons using the Editor Extension tool in ArcGIS while the volume and surface area between the reference polygon for each section and the TIN surfaces were calculated using the $3 D$ Analyst Triangulated Surface Polygon Volume Tool. The attribute tables of the respective reference polygons were automatically populated with the volume and surface area results for the respective sections which were extracted for further analysis. The process of volume calculation was repeated at different reference heights until the highest elevation with zero volume and surface area was obtained. This elevation corresponds with the channel bed elevation above mean sea level since the Digital Elevation Model (Digital Terrain Model) used gave the ground surface elevation. The same procedure was repeated for both DEMs (2000 and 2011) and the percentage loss in Volume and surface area at the 29 sections for the respective elevations were calculated using Microsoft Office ${ }^{\circledR}$ Excel 2007. The change in channel bed elevation between 2000 and 2011 (Loss in flow depth), the average annual loss in flow depth as well as estimated bed elevation and loss in flow depth for 2016 were also calculated using the same application.

Student's T-test statistics was used to compare the channel bed elevations of 2000 with 2011 at 95\% Confidence Level using Minitab ${ }^{\circledR}$ 14.12.0 Statistical Software. A $P$-value $<0.05$ was accepted as statistically significant.
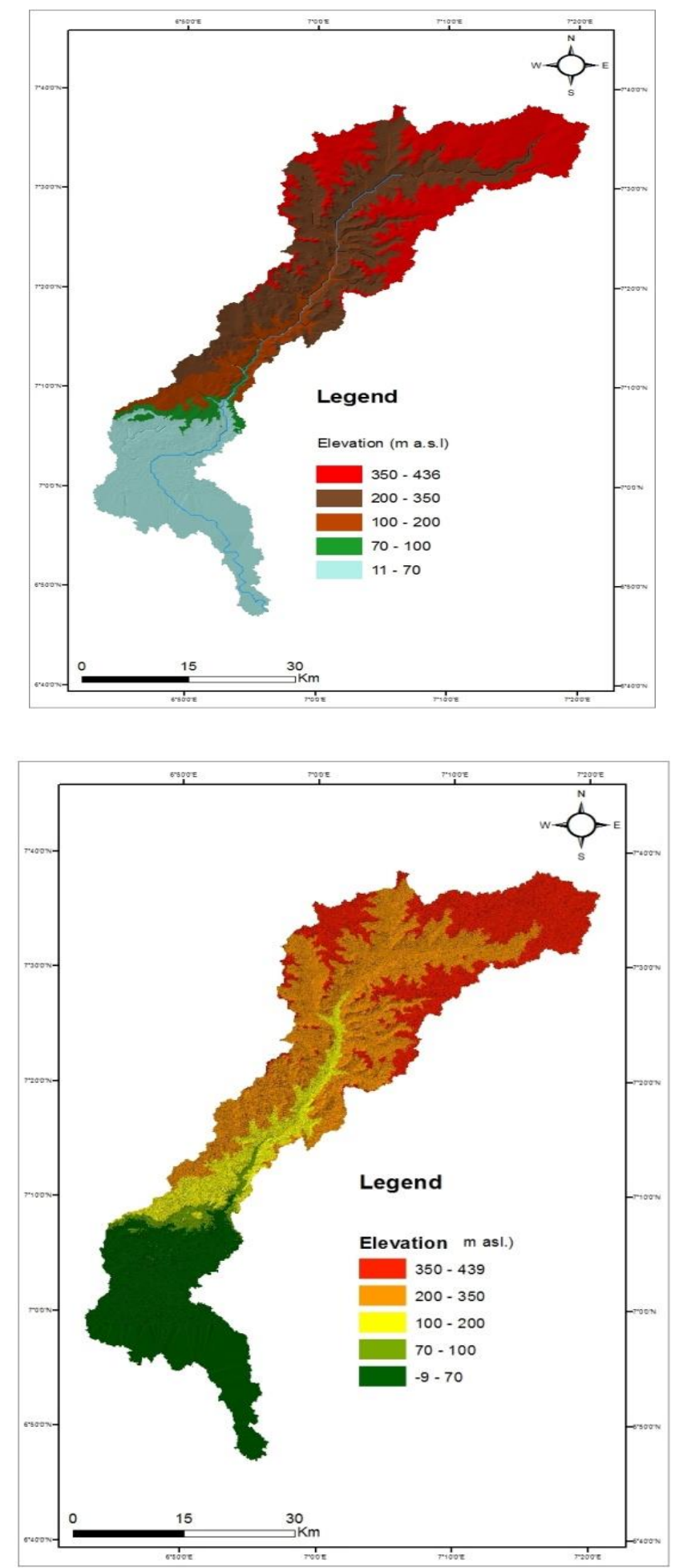

Figure 2: Triangulated Irregular Network (TIN) surface for 2000 and 2011 


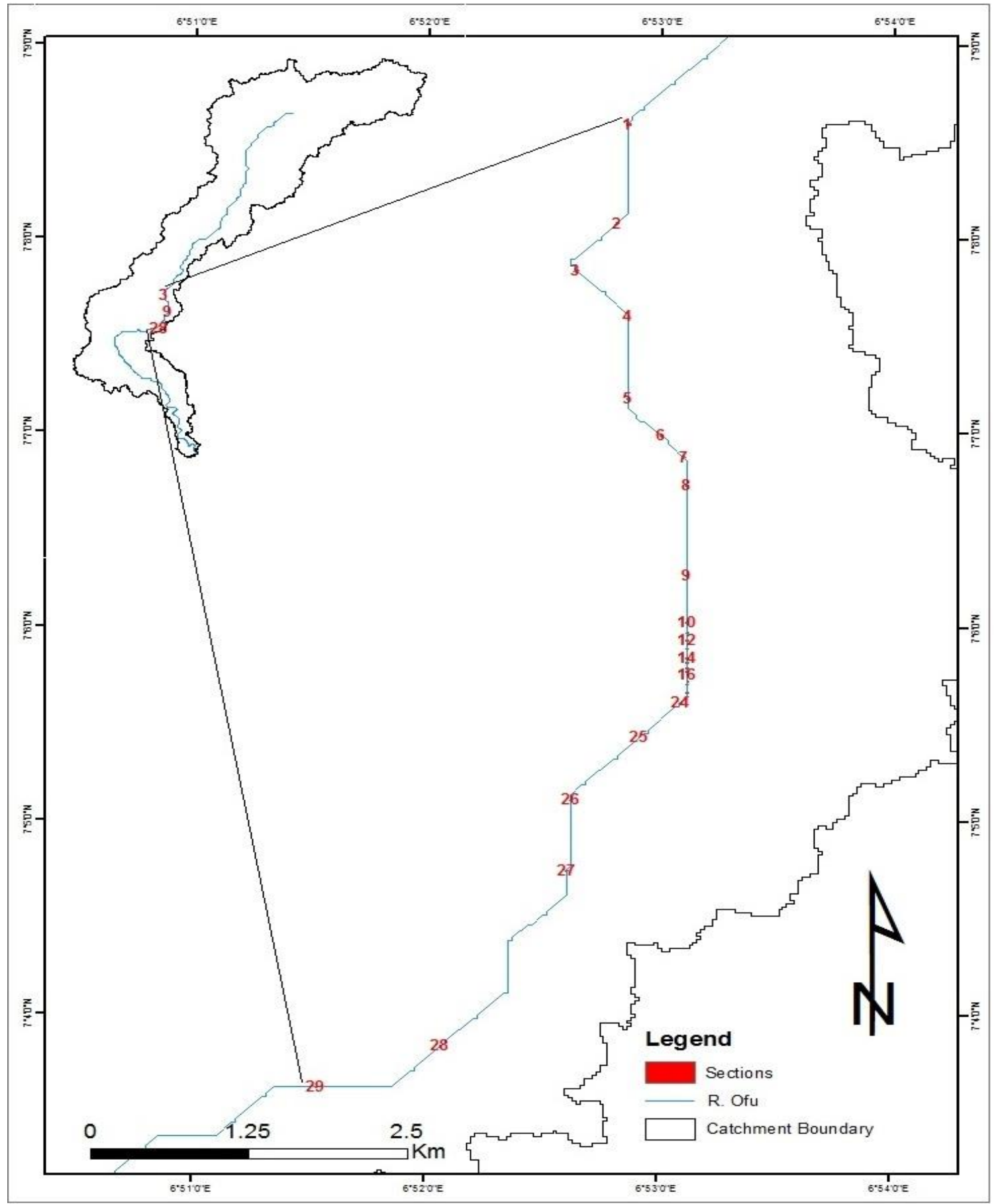

Figure 3: Location of sections for Ofu River Volume estimation at Oforachi

\subsection{Quantification of the Sediment Load of Ofu River at} Oforachi Station

The total sediment load for Ofu River at Oforachi was estimated as a combination of the measured and unmeasured sediment loads as recommended by the US Army Corps of Engineers [15]. The measured sediment load is mainly the suspended sediments while the unmeasured loads include some of the unaccounted suspended load, within the lower $0.15 \mathrm{~m}$ depth portion of a sampled water column and the entire bed load.
In order to measure the suspended sediment load, the river cross-section at Oforachi Bridge Hydrometric Station was divided into three equal verticals of $1 / 4,1 / 2$, and $3 / 4$ width as recommended by the World Meteorological Organization's Guide to Hydrologic Practices [16] after which a standard lightweight handheld US DH-48 sediment sampler was used to collect samples from these verticals [17]. The samples from the three verticals were mixed thoroughly to obtain a representative sample for laboratory analysis to 
determine the sediment concentration in the sample. The samples were quickly taken to the Sanitary Chemistry Laboratory of the Department of Water Resources and Environmental Engineering, Ahmadu Bello University Zaria for analysis. Standard method for estimating suspended solids in water was used to estimate the suspended sediment concentration in $\mathrm{mg} / \mathrm{l}$ [18]. The measurement of suspended sediment concentration of Ofu River at Oforachi was done across 12 months beginning from February, 2016 to January 2017. A total of 22 measurements were carried out which were used to develop a suspended sediments versus River discharge rating curve. The rating curve was then used to estimate the suspended sediment concentration for other days of no measurement. The discharge values used were measured at the same time the results of which have been published previously [19]. The Measured sediment discharge, $Q_{m s}(\mathrm{~kg} /$ day) was calculated using Eq. (1) [15, 20]:

$$
Q_{m s}=K c Q
$$

Where $Q_{m s}$ is Measured sediment discharged (kg/day), c is sediment concentration $(\mathrm{mg} / \mathrm{l}), \mathrm{Q}$ is River discharge $\left(\mathrm{m}^{3} / \mathrm{s}\right)$ and, $\mathrm{K}=86.4$. The value of $c$ was obtained as the concentration of the sampled sediments using a standard lightweight hand-held US DH-48 sediment sampler, Q was obtained from an established stage-discharge relationships for Ofu River at Oforachi Bridge Hydrometric Station [19].

The Colby's method for estimating unmeasured sediment load described in detail previous by Otun and Adeogun [17] was used in the study. As a result 22 unmeasured sediment discharges, $Q_{u s}$ (tonnes/day) were measured and regressed on the corresponding River discharge values to develop a relation which was used to estimate unmeasured sediment load for the 12 months. The total sediment load $Q_{t o t}$ was calculated using Eq. (2):

$$
Q_{t o t}=Q_{m s}+Q_{u s}
$$

Where, $Q_{t o t}$ is the total sediment load, $Q_{m s}$ is the measured sediment load and $Q_{u s}$ is the unmeasured sediment load.

\section{RESULTS AND DISCUSSIONS}

The results of the percentage loss in volume of ofu River channel for all sections are presented in Fig. 4. The percentage loss in volume ranged from a minimum of $36.3 \%$ at section 26 to a maximum of $96.4 \%$ at section 6 with an average of $62 \pm 18.9 \%$. More so, the percentage loss in surface area of Ofu River for the respective sections is presented in Fig. 5.

Unlike the volume, the surface area between 2000 and 2011 decreased marginally for 15 sections and significantly for two sections ( 1 and 6 ) while marginal increase were observed for 12 sections. The average loss in surface area was $2.55 \%$ with a standard deviation of $10.1 \%$. Two outliers were observed at sections 1 and 6 which implies that the percentage loss in surface area for the 29 sections probably did not follow a normal distribution thus could not be adequately described by the means and standard deviation. The skewness of 3.94 calculated also buttresses this assertion. Thus the loss in surface area was better described using the median and interquartile range $(0.06 \%$ and $1.498 \%$ respectively). The summary of the channel bed elevations for 2000 and 2011, losses and the loss per annum are presented in Table 1.

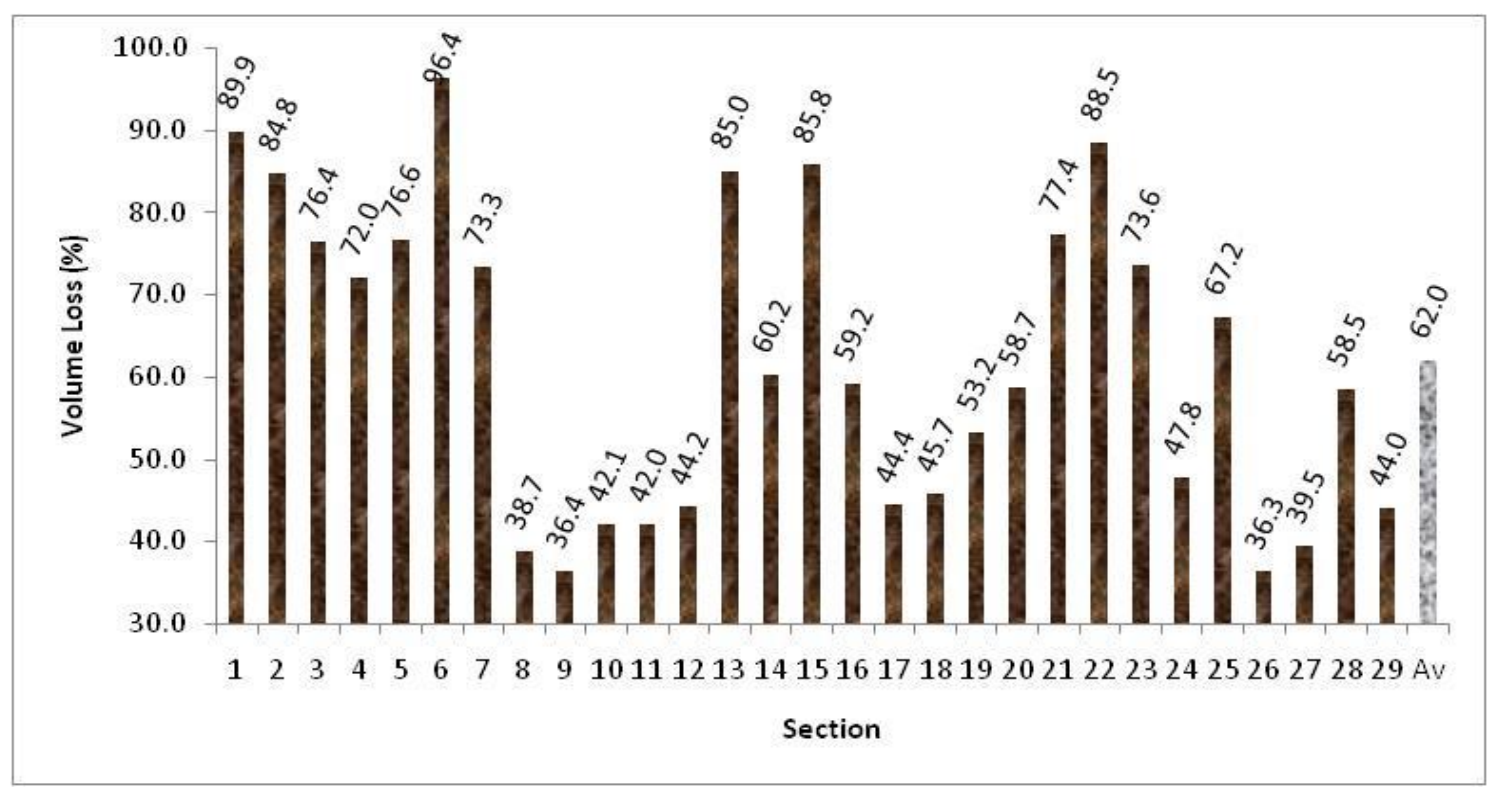

Figure 4: Percentage Loss in River Volume between 2000 and 2011 


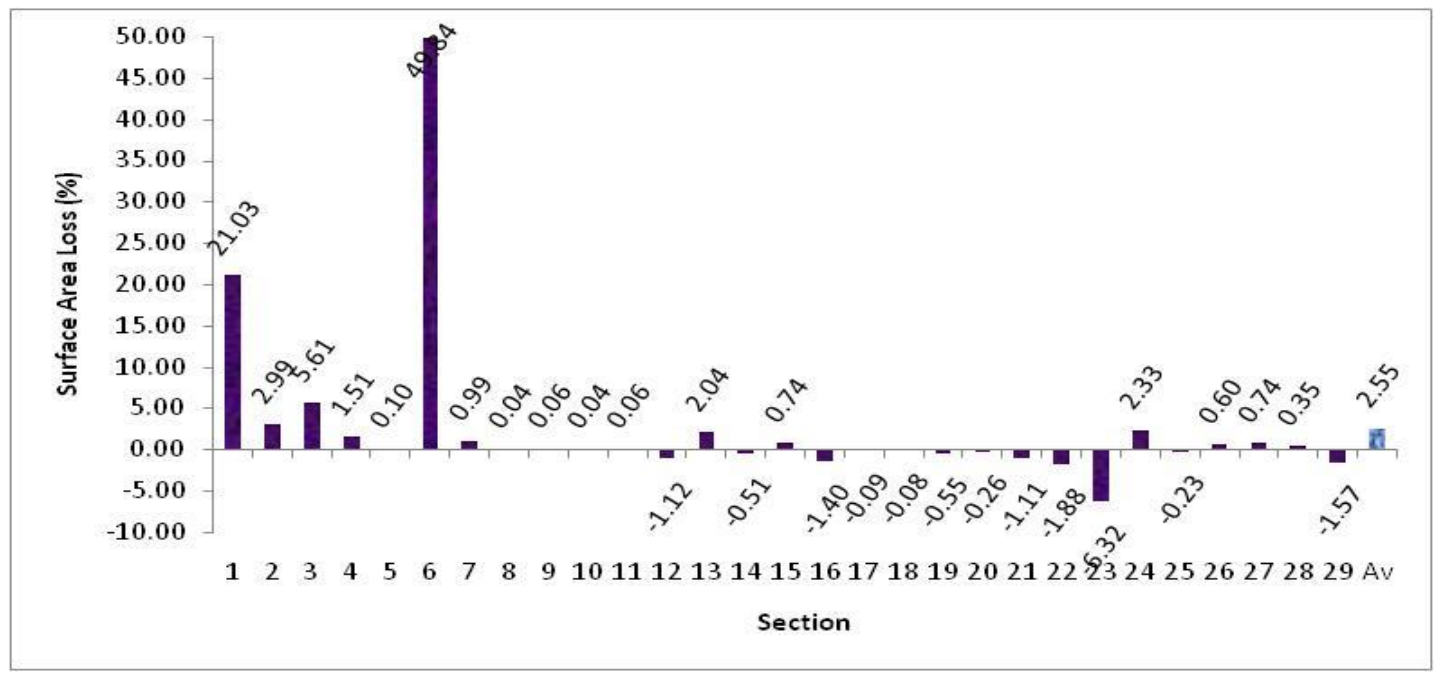

Figure 5: Percentage Loss in River Surface Area between 2000 and 2011

Table 1: Summary Results of Channel Bed Elevations (2000 and 2011), Bed Elevation Loss, Loss Rate and T-test

\begin{tabular}{lcccccc}
\hline & Mean \pm SD & Minimum & Maximum & Median & IQR & $P$-Value \& 95\% CI \\
\hline 2000 Bed Elevation (m asl.) & $30.248 \pm 4.031$ & 21.270 & 37.240 & 31.110 & 7.095 & $0.000 ;$ \\
2011 Bed Elevation (m asl.) & $43.129 \pm 4.069$ & 36.270 & 49.880 & 42.650 & 7.000 & $11.226-14.538$ \\
Loss (m) & $12.882 \pm 4.353$ & 7.250 & 23.150 & 11.250 & 7.355 & \\
Loss/Annum (m/year) & $1.171 \pm 0.396$ & 0.659 & 2.105 & 1.023 & 0.669 & \\
\hline
\end{tabular}

$S D=$ Standard deviation; $I Q R=$ Inter quartile range; $C I=$ Confidence Interval

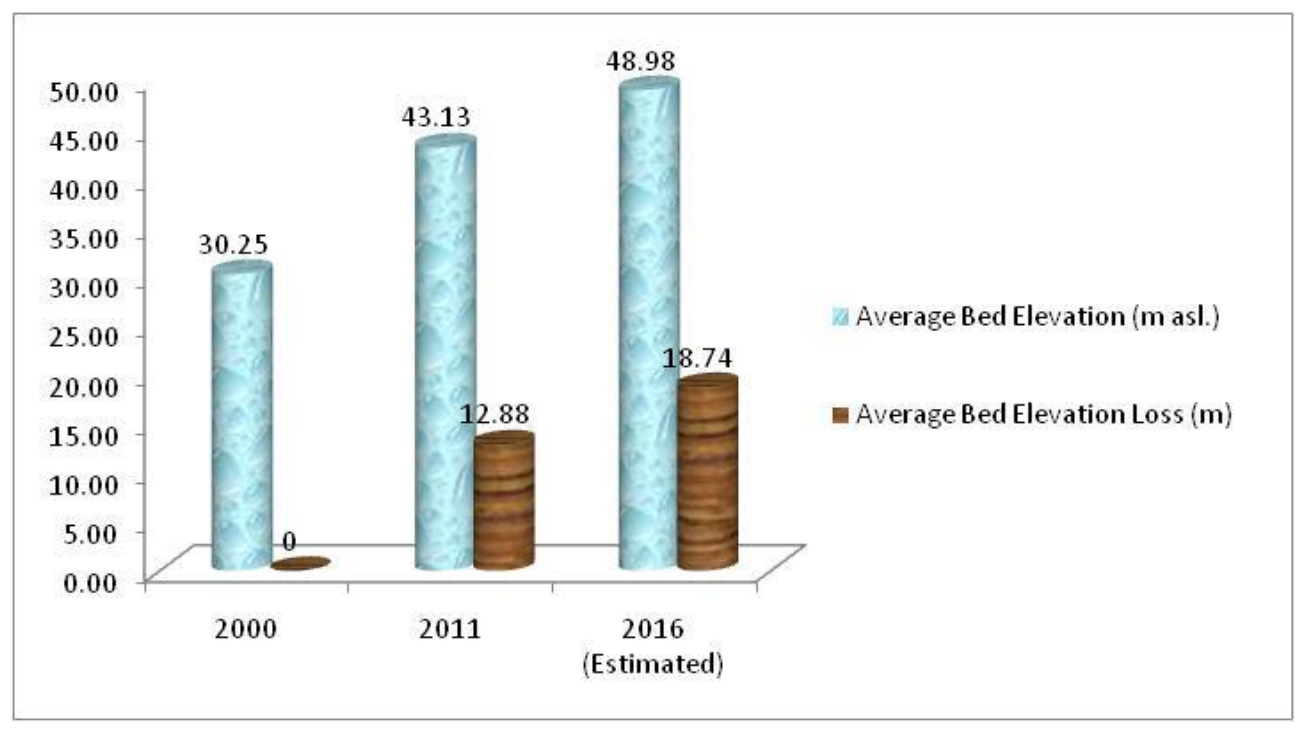

Figure 6: Loss in Channel depth between 2000, 2011 and 2016 (estimated) at Oforachi.

The results in Table 1 also show the $P$-value and 95\% confidence interval obtained from the paired t-test carried out to compare the channel bed elevations for 2000 and 2011. The $P$-value and the 95\% confidence interval obtained confirm that the difference between the channel bed elevations for 2000 and 2011 were statistically significant at $95 \%$ confidence level. This confirms there is an actual loss in the flow depth of the river over this period which could be attributable to increasing sedimentation. Furthermore, the average bed elevations for 2000 and 2011, bed elevation loss as well as estimated bed elevation and loss for 2016 are presented in Fig. 6.

The Ofu River bed elevation in 2000 and 2011 were $30.25 \mathrm{~m}$ and $43.13 \mathrm{~m}$ above mean sea level, respectively. This implied that a loss in flow depth of $12.88 \mathrm{~m}$ had occurred between 2000 and 2011 at an annual rate of $1.17 \mathrm{~m}$ (Table 1). Based on this, the bed elevation in 2016 was estimated to be $48.98 \mathrm{~m}$ above mean sea level implying a loss in flow depth of $18.74 \mathrm{~m}$. 
(61.95 \%) between 2000 and 2016. This loss was actually confirmed by residents of community that the river used to be deeper than it was at the time of this study.

The implication of extent of loss is that the carrying capacity of Ofu River had reduced by about $47 \%$. The floodwater that could be contained by the river channel in 2000 could actually end up overflowing the banks and the floodplain with this extent of flood. This probably explains why the communities within the Ofu River floodplains have been experiencing flood on annual basis any time there is a prolonged rainfall especially in August and September. This loss in flow depth may be attributable to probably siltation of the River which could be as a result of farming activities within the floodplain that probably has increased the erodibility of the soil. The Ofu River channel bed profile for 2000, 2011 and 2016 are presented in Fig. 7.

\subsection{Quantification of the Sediment Load of Ofu River at Oforachi Station}

The respective relationships of the suspended sediment concentrations and unmeasured sediment loads with the River discharges (Figs. 8 and 9) follow a power curve in agreement with previous studies [17, 21].

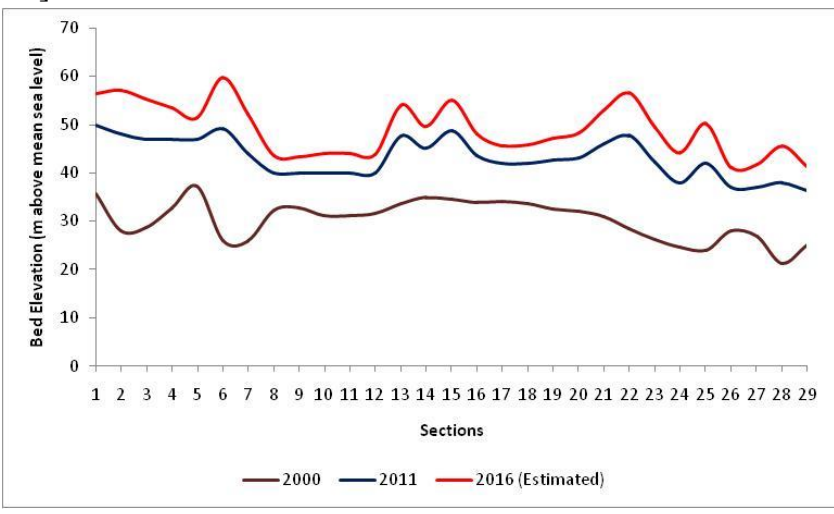

Figure 7: Ofu River Channel Bed profile for 2000, 2011 and 2016

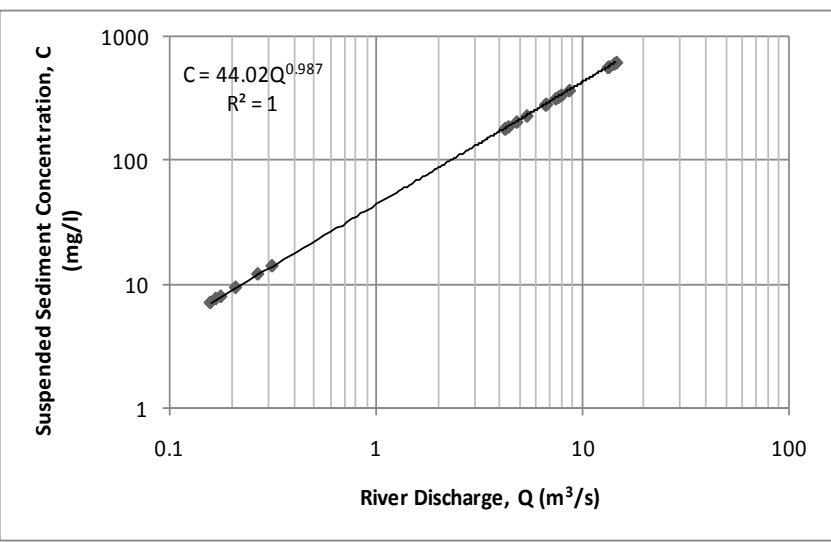

Figure 8: Plot of Suspended Sediment Concentration vs Ofu River Discharge at Oforachi Station

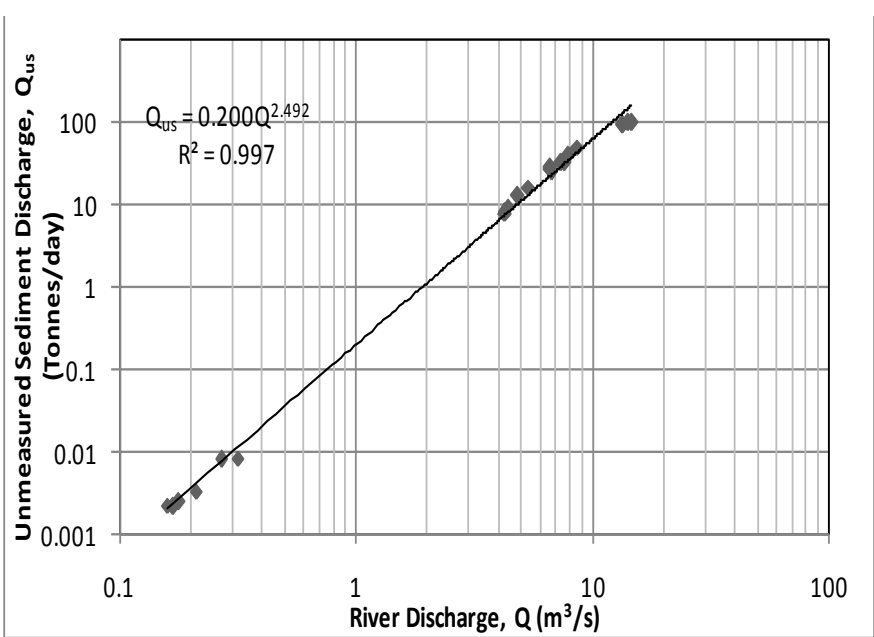

Figure 9: Plot of Suspended Sediment Concentration vs Ofu River Discharge at Oforachi Station

More so, the sediment loads of Ofu River at Oforachi hydrometric station are presented in Table 2. It is clearly indicated in Table 2 that the measured sediment loads for Ofu River is $56,747,260 \mathrm{~kg} /$ year while the unmeasured sediment loads is $10,077,470 \mathrm{~kg} /$ year. While this trend is similar to the results of Otun and Adeogun [17], the values obtained herein are far higher than the $14,944,000 \mathrm{~kg} /$ year and 1,125,000 kg/year obtained respectively for Samaru River. Table 2 further shows that January has the lowest total sediment load of $3,030 \mathrm{~kg} /$ month while the highest total sediment load of $24,596,840 \mathrm{~kg} /$ month was recorded in the month of August. As noted by the US Army Corps of Engineers [15], the unmeasured sediment loads comprise of the bed load and suspended materials within $0.15 \mathrm{~m}$ from the river bed. Thus this unmeasured sediment accounts for the loss in flow depth recorded in this study. However, the annual sediment load of Ofu River at Oforachi bridge hydrometric station was $66,824,730 \mathrm{~kg}$ which further confirms not just the loss in flow depth but the fact that it will continue to increase. The high values of the suspended sediment concentration are indicative of the significant disturbances of nearby fields used for Agricultural activities.

\subsection{Ground Truthing}

The coordinates of the staff gauges established in the course of stage measurement [19] were plotted in ArcGIS 10.2.2 as shown in Fig. 10 as a form of ground truthing. It can be seen that the point actually fall on Ofu River feature as shown in Fig. 10. 
Table 2: Monthly and Annual Sediment Loads of Ofu River at Oforachi Hydrometric Station

\begin{tabular}{llll}
\hline Month & $\begin{array}{l}\text { Measured Sediment Load (x } \\
10^{3} \mathrm{~kg} / \text { Mnth) }\end{array}$ & $\begin{array}{l}\text { Unmeasured Sediment Load (x } \\
10^{3} \mathrm{~kg} / \text { Month) }\end{array}$ & $\begin{array}{l}\text { Total } \\
\left(\mathrm{x} 10^{3} \mathrm{~kg} / \mathrm{Month}\right)\end{array}$ \\
\hline January & 2.97 & 0.06 & 3.03 \\
February & 5.06 & 0.12 & 5.19 \\
March & 493.38 & 43.73 & 537.11 \\
April & $1,473.27$ & 152.64 & $1,625.91$ \\
May & $2,413.80$ & 280.83 & $2,694.64$ \\
June & $3,357.49$ & 434.42 & $3,791.91$ \\
July & $2,963.78$ & 358.72 & $3,322.50$ \\
August & $20,534.27$ & $4,062.57$ & $24,596.84$ \\
September & $20,405.29$ & $4,041.63$ & $24,446.92$ \\
October & $5,088.56$ & 702.50 & $5,791.06$ \\
November & 5.87 & 0.15 & 6.02 \\
December & 3.52 & 0.08 & 3.60 \\
\hline Total & $56,747.26$ & $10,077.47$ & $66,824.73$ \\
(x103 kg/Annum) & & & \multirow{2}{*}{. } \\
\hline
\end{tabular}

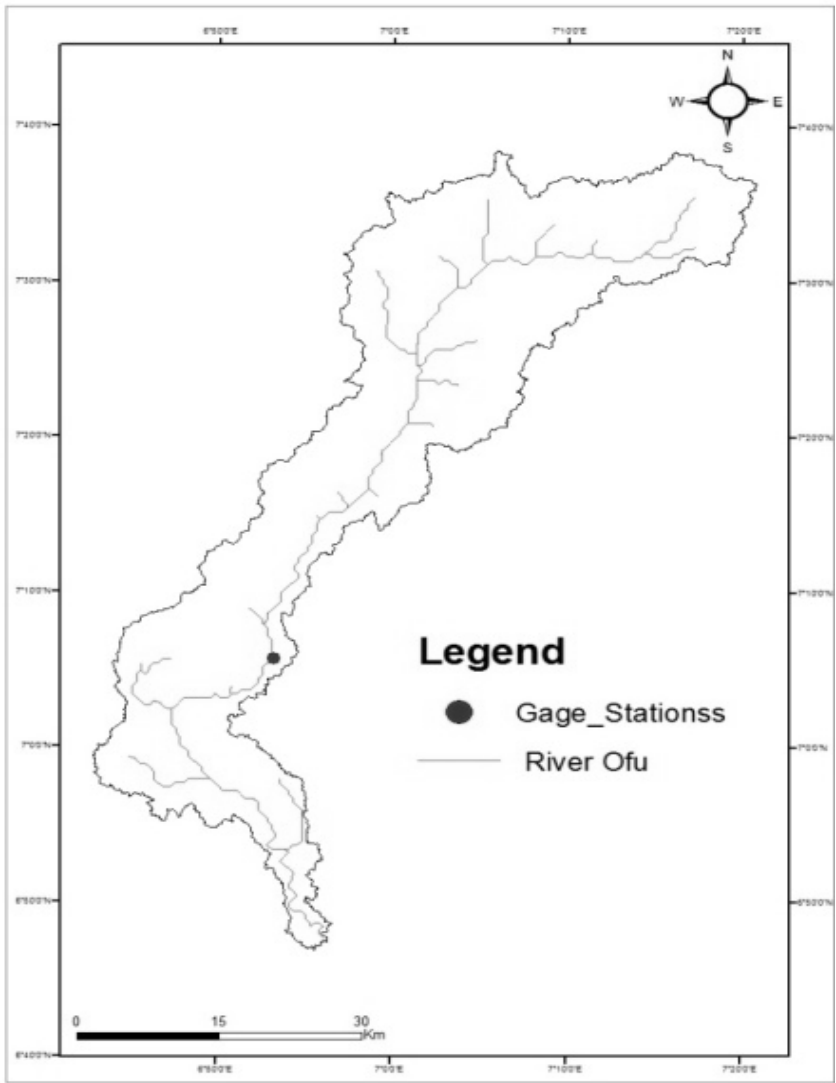

Figure. 10: Ofu River catchment showing location of gauge stations [19]

\section{CONCLUSIONS}

The study has demonstrated that remote sensing and GIS can be used to assess the changes in the dischargecarrying capacity of a river. The study shows that Ofu River has lost $12.88 \mathrm{~m}$ amounting to about $42.58 \%$ of its flow depth at Oforachi between 2000 and 2011 at a rate of $1.171 \mathrm{~m}$ per year and an estimated $18.74 \mathrm{~m}$ amounting to about $61.95 \%$ in 2016 which is the major cause of flood within the floodplain. Due to this extent of loss, the river overflows its banks with any prolonged rainfall. The annual sediment load of Ofu River at Oforachi bridge hydrometric station was found to be $66,824,730 \mathrm{~kg}$ which explains the loss in flow depth recorded. The high sediment loads is probably as a result of soil cultivation within the catchment since the major occupation is farming. There is therefore an urgent need for a possible dregding of the river to create more flow capacity that can contain floodwater.

\section{REFERENCES}

[1] Coto, E. B. Flood hazard, vulnerability and risk assessment in the city of Turrialba, Costa Rica. International Institute for Geo-information Science and Earth Observation (ITC), 1-102, 2002.

[2] Ajin, R., Krishnamurthy, R., Jayaprakash, M., and Vinod, P. "Flood hazard assessment of Vamanapuram River Basin, Kerala, India: An approach using Remote Sensing \& GIS techniques, Advances in Applied Science Research, Vol. 4, Number 3, 263-274, 2013

[3] Obeta, M. C. "Institutional Approach to Flood Disaster Management in Nigeria: Need for a Preparedness Plan", British Journal of Applied Science \& Technology, Vol. 4, Number 33, 45754590, 2014. 
[4] Komolafe, A. A., Adegboyega, S. A.-A., \& Akinluyi, F. 0. "A Review of Flood Risk Analysis in Nigeria", American Journal of Environmental Sciences, Vol. 11, Number 3, 157-166, 2015.

[5] Adebayo, A. A., and Oruonye, E. D. "An Assessment of the effects of the 2012 Floods in Taraba State, Nigeria", Annual National Conference, organized by the Association Hydrological Science University of Agriculture, Abeokuta, Ogun, state, Nigeria, 2013.

[6] Galy, H. M., \& Sanders, R. A. Using SAR imagery for flood modeling. Englewood, CO. http://WWW. intermap. ca/PDF/rgs_paper. pdf (22 February 2000). 2000.

[7] Nwafor, J. C. Environmental impact assessment for sustainable development: the Nigerian perspective. Environment and Development Policy Centre for Africa (EDPCA). 2006.

[8] Jeb, D. N and Aggarwal, S.P. "Flood inundation hazard modeling of the River Kaduna using Remote Sensing and Geographic Information Systems", Journal of Applied Sciences Research, Vol. 4 Number 12, Pp. 1822-1833, 2008.

[9] Olajuyigbe, A. E., Rotowa, O. O., and Durojaye, E. "An assessment of flood hazard in Nigeria: The case of mile 12, Lagos", Mediterranean Journal of Social Sciences, Vol. 3, Number 2, Pp. 367-375, 2012.

[10] Smith, K. and Ward, R. Floods Physical Processes and Human Impact, Johnn Willy and Sons, WestSussex, England, 1998.

[11] Alfa, M. I., Ajibike, M. A, Adie, D. B. and Mudiare, O. J. "Assessment of the Effect of Land Use /land Cover Changes on Total Runoff from Ofu River Catchment in Nigeria", Journal of Degraded and Mining Lands Management, Vol. 5, Number 3, pp 1161-1169, 2018.

[12] Alfa, M. I. "Flood Risk Assessment of Ofu River Catchment in Nigeria". Unpublished PhD Thesis in the Department of Water Resources and Environmental Engineering, Ahmadu Bello University, Zaria, Nigeria, 2018.
[13] Gideon, Y. B., Fatoye, F. B. and Omada, J. I. "Quality Assessment of Physico-Chemical Characteristics of Okura River, Kogi State, Nigeria", International Journal of Science and Technology, Vol. 2, Number 12, pp 891-899, 2013.

[14] AR-AR Partnership: Oforachi Irrigation Project Contract Documents Volume III: Main Report Prepared for Lower Benue River Basin Development Authority, Federal Republic of Nigeria, 2004 (Unpublished).

[15] U.S. Army Corps of Engineers: Sediment Measurement Techniques (Em 1110-2- 4000; Ch 8). www.usace army.mil; 1995.

[16] World Meteorological Organisation: Guide to Hydrological Practices. Fifth Edition, WMO-No. 168, Geneva; 1994.

[17] Otun, J. A. and Adeogun, B. K. "Analysis of Fluvial Sediment Discharges into Kubanni Reservoir", Nigerian Journal of Technology, Vol. 29, Number 2, pp 64-75, 2010.

[18] American Public Health Association: Standard Methods for the Examination of Water and Wastewater, 20th ed. Jointly published by American Public Health Association (APHA), American Water Works Association (AWWA) and Water Environment Federation (WEF), Washington, USA, 2012.

[19] Alfa, M. I., Ajibike, M. A, Adie, D. B. and Mudiare, O. J. "Development of Rating Curve for Ofu River at Oforachi Hydrometric Station", Nigerian Journal of Technological Development, Vol. 15, Number 1, pp 14-19, 2018.

[20] Ongley, E.: Sediment Measurement in Water Monitoring- A Practical Guide to the Design and Implementation of Freshwater Quality Studies and Monitoring Programmes Ed. Jamie B. \& Richard B. United Nation Environment Programme and The World Health Organisation; 1996.

[21] Warrick, J. A. "Trend analyses with river sediment rating curves", Hydrological processes, Vol. 29, Number 6, pp 936-949, 2015. 